\title{
The moderating effect of intellectual capital on the rela- tionship between corporate reputation and knowledge sharing of commercial banks
}

\author{
Romel C. Nemiño ${ }^{1 *}$, Gloria P. Gempes ${ }^{2}$ \\ ${ }^{1,2}$ University of Mindanao, Davao, Philippines
}

\section{Keywords \\ Management \\ Intellectual capital \\ Corporate reputation \\ Knowledge sharing \\ Commercial banks \\ Philippines}

Received: 13 March 2018

Accepted: 27 April 2018

Published: 6 June 2018

\begin{abstract}
The ultimate aim of this study is to determine the moderating effect of intellectual capital on the relationship between corporate reputation and knowledge sharing of commercial banks in the Caraga Region, Philippines. Its objectives are to determine the levels of corporate reputation, knowledge sharing, and intellectual capital. Also, correlations between corporate reputation on knowledge sharing and intellectual capital on knowledge sharing were studied. Adapted survey questionnaires were given to a sample of 400 bank employees of various commercial banks in the region using a stratified sampling technique. Results uncovered that the three constructs have a very high level as perceived by the bank personnel. Findings revealed that corporate reputation is significantly related to knowledge sharing. Intellectual capital also showed a significant positive relationship towards knowledge sharing. To determine the moderating effect of intellectual capital, hierarchical logistic regression was employed in this study. Results revealed that intellectual capital demonstrates a significant moderating effect on the relationship between corporate reputation and knowledge sharing. Employees who have higher intellectual capital also have a higher level of corporate reputation towards knowledge sharing. Having said this, the proposed research model in this study may be considered by the business enterprises, in general, by revisiting their current platforms and policy formulations and reviews on corporate reputation towards knowledge sharing with the complementary effect of intellectual capital. With these three constructs as a support system, superior performance and competitiveness among commercial banks and other business organizations may be expected. With the growing economic activities nowadays, especially that ASEAN development is already taking place in the ASEAN member countries where the Philippines is a member of, commercial banks have to sustain their competitive position amidst the challenging competition in the banking industry.
\end{abstract}

(c) 2018 The Author(s). Published by TAF Publishing.

\section{INTRODUCTION}

The concept of sharing knowledge to various people and other sectors contribute to developing knowledge in order for them to freely explain and express opinions on possible issues that motivate on creating an emerging knowledge (Alshehhi, 2016; Due Au, 2016; Fernie, Green, Weller, $\&$ Newcombe, 2003). However, people hoard knowledge and in the past decades, companies felt minute effect from people who hoard information since firms could innovate and move their operations forward (Emelo, 2012; Ketsiri, 2016). Some reasons to believe why employees do not have the desire to share their knowledge amidst the vital role of knowledge sharing in developing the enterprise's knowledge in the organizations. In an instance, Michailova and Husted (2003) in their study disclosed varying issues on the employees' hesitance to impart knowledge. These constitute their apprehensions of diminishing one's worthiness, the various costs incurred, not quite sure on the receiver's response when knowledge is shared, recognizing the "hierarchy" of having the power, the possible unlikely effects of having the knowledge shared within them and with others. For Oye, Salleh, and Noorminshah (2011), the strongest reason why employees do not share knowledge is the lack of job security.

${ }^{*}$ corresponding author: Romel C. Nemiño

†email: tomcat950@gmail.com 
Recognition of knowledge plays both an essential recourse of the organization and a laying ground for "competitive advantage" e.g., (Lannu, 2017; Wenger, McDermott, \& Snyder, 2002). In order to achieve it, information and one's skills and talents must be mobilized from the experts up to those who desire it (Hinds, Patterson, \& Pfeffer, 2001). The preceding literature on knowledge sharing has brought much interest for the researchers of today. The underlying problems and the degree of its importance in the eyes of the stakeholders have led to the foundation of this study. With this, the researcher conducted an intensive review of the literature for possible association of variables that may affect or moderate intellectual capital. Prior studies and literature have found that corporate reputation is associated with knowledge sharing. One example of this was a study conducted by Ensign and Hébert (2010) which argued that reputation was associated with knowledge sharing on the pharmaceutical scientists working at the Research and Department operations of various pharmaceutical companies in Canada and the United States. Further, intellectual capital is also associated with knowledge sharing. Ngah and Ibrahim (2011) also contended a positive connection of the dimensions of intellectual capital on knowledge sharing. It is on the foregoing context that the researcher made to decide to conduct the study in order to fill the gap with the intent of determining which of the aforesaid variables may have directly contributed or moderated the impact of one construct to the other. Despite the fact that there are already prior related literature in the association between corporate reputation and knowledge sharing as well as the intellectual capital construct linked with knowledge sharing, those studies exhibited with bivariate relationships only and were not able to cover the three variables in a single study. Although these constructs are interrelated with each other, they are rarely discussed together in one single study making it sparse in the extant literature. This research fills the gap and puts forth a novel construction integrating the three variables in one study where one variable is the moderating construct. Such findings will lead to the frontier of new knowledge.

\section{Objectives of the Study}

This empirical study investigated in determining the moderating effect of intellectual capital on the relationship between corporate reputation and knowledge sharing of commercial banks in Caraga Region. Specifically, the study dealt on the following objectives:

a. To assess the level of corporate reputation, knowledge sharing, and intellectual capital of commercial banks. b. To determine the significant relationship between corporate reputation and knowledge sharing as well as the significant relationship between intellectual capital and knowledge sharing of commercial banks.

c. To determine the significance of the moderating effect of intellectual capital on the relationship between corporate reputation and knowledge sharing of commercial banks.

\section{LITERATURE REVIEW}

This chapter presents the review of related literature and related studies conducted in local and international setting which essentially contributes to the conceptualization of this study. These comprise corporate reputation, knowledge sharing, and intellectual capital.

\section{Corporate Reputation}

There are many factors that affect corporate reputation (Bromley, 2001; Musteen, Datta, \& Kemmerer, 2010) and one of these is personal reputation. The image of the leader or the owner or the management impacts the firm's reputation. The leader's reputation brings significance in identifying the firm's reputation as this has been highlighted in many studies the fact that the leader makes up fortyeight percent of the firm's reputation (Kinata, 2016; Klein, 1999; Grupp \& Gaines Ross, 2002). Corporate reputation is very essential to the firms that continuously seek and sustain admiring "attitude" into the hearts of their customers and stakeholders. Primarily, reputation is a basis utilized mainly by possible clients to select their very own service providers (Walsh, Mitchell, Jackson, \& Beatty, 2009). Second, a favorable corporate reputation will more likely increase customers to keep on coming back, attract greater volume of customers (Gardberg \& Fombrun, 2002; Wasike, 2017), will build impediments upon entering into the marketplace for those would-be competitors (Nguyen \& Leblanc, 2001), and may eventually yield in a much bigger worth in the marketplace (K. T. Smith, Smith, \& Wang, 2010). Customers may as well view firms with an appreciative image and complementary remarks, such as accountability, dependability, trustworthiness, and integrity, as opined by (Fombrun, 1995) aside from perceived "quality" and "prestige" (Rindova, Williamson, Petkova, \& Sever, 2005), directing to profound customer delightful remarks of the organization's ability to render outstanding products and/or services to include sincerity by fulfilling the conditions and agreements.

\section{Knowledge Sharing}

Studies on knowledge sharing have brought major significant contributions in the research arena. Chennamaneni 
(2007) contended that the key player of knowledge management that has been determined is knowledge sharing. Sharing of knowledge is recognized as a pivotal endeavor to achieve organizational objectives, especially in a rapid evolving community where there is a rising issue to address the demands of the customers as well as the strategies involved (Bo Shing, 2017; Lin, Che, \& Ting, 2012; Wasko \& Faraj, 2005; Renzl, 2008). From the viewpoint of King (2009), the concept of knowledge relates to one's faith of justification. A quite number of classifications specifying different forms of knowledge are taking place and the most common differentiation is the explicit and tacit forms of knowledge. Noe (2008) defines tacit knowledge as personal knowledge as one that is derived from individual experiences and influenced by varying perceptions and values. On the other hand, explicit knowledge pertains to formulas, guides, and other technicalities which are translated into useful language. This explicit knowledge may be handled by putting it in a knowledge depository system. However, explicit knowledge comes in a context of documents which are translated into words.

\section{Intellectual Capital}

The concept of Intellectual Capital (IC), in its broadest sense, has a lot of categories to study into. Notable authors have defined this concept in a number of ways. The concept of IC was first launched in 1969 by Jon Kenneth Galbraith (Chang \& Hsieh, 2011). It mainly pertains to the available means that identify the organization's worth while being competitive at the same time. It is a broad spectrum which divides into various classifications known (Abdullah \& Sofian, 2012) as the relational capital, structural capital, and the human capital. Stewart (1997) defines the concept of intellectual capital as the "intellectual material" that is formal, capturing, and leveraging to yield wealth by creating an asset of greater value. For Ismail (2005), he proposed the involvement of the spiritual capital as an additional dimension of the intellectual capital components. He defined it as "the intangible knowledge, faith, and emotion embedded in the minds of individuals and in the heart of the organization which includes vision, direction, guidance, principles, values, and culture". For Stewart (2007), human capital refers to the increasing abilities of the individuals who are the main actors in addressing "customer solutions". Relational capital refers to the profound relationships of the organizations towards its customers and stakeholders. Structural capital refers to the organization's capacity to meet "market requirements".

\section{Hypothesis}

Investigations on this research were designed to test hypotheses about the effects of different treatment conditions. The following null hypotheses in the study were tested at 0.05 level of significance:

1. There is no significant relationship between

a. corporate reputation and knowledge sharing of commercial banks.

b. intellectual capital and knowledge sharing of commercial banks.

2. There is no significant moderating effect of intellectual capital on the relationship between the corporate reputation and knowledge sharing of commercial banks.

\section{RESEARCH MODEL}

A conceptual paradigm of the study is articulated in figure 1 linking each of these constructs to knowledge sharing of commercial banks. The empirical study has corporate reputation as the independent variable which is basically utilized as an indicator by organizations to gain customers' trust in delivering products or services (Herbig \& Milewicz, 1995). In this study, questionnaire was adapted from (Chen, 2017). The second variable is the intellectual capital being the moderating variable. In this study, the research instrument was adapted from Ismail (2005). The dependent variable pertains to the knowledge sharing where the questionnaire was adapted from (McGrane, 2016). A moderator variable, that is, the intellectual capital, explains the relation between corporate reputation being the predictor and knowledge sharing being the criterion variable. A moderator is a variable that affects (Tsang, 2015) the strength of the relation between the predictor and the criterion variable. The modified questionnaire was submitted for validity by the panel of validators and the test for reliability was determined by Cronbach's alpha that resulted to 0.955 which proved that the instrument has a high level of internal consistency. To consider some ethical issues prior to data gathering, this study has undergone intensive review by the University of Mindanao Ethics Review Committee (UMERC). 


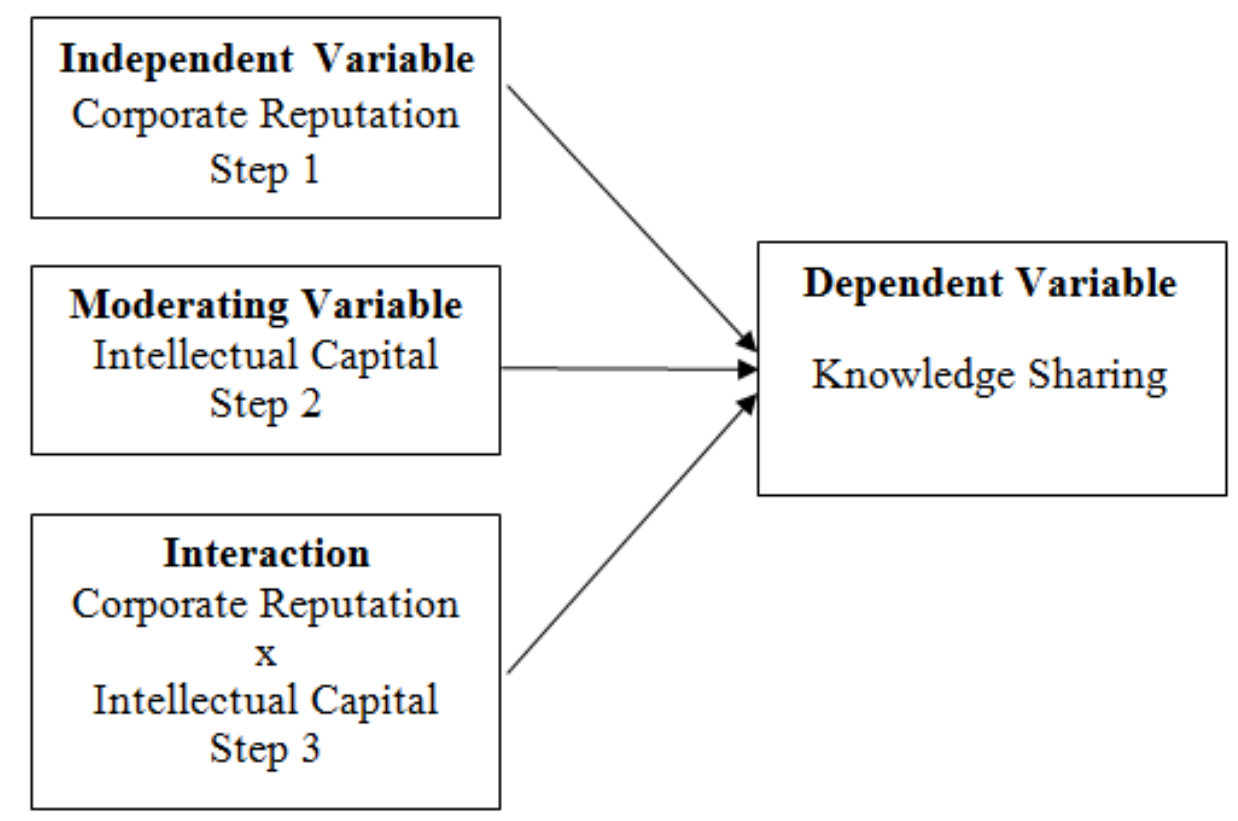

FIGURE 1. The conceptual paradigm of the study

\section{DATA ANALYSIS \& RESULTS}

Presented in Table 1 is the level of corporate reputation of commercial banks. The overall mean of the level of corporate reputation is 4.67 having a descriptive level of very high. Knowledge sharing has an overall mean of 4.33 which also results into a very high descriptive level. The intellectual capital, another construct, has its overall mean of 4.63 which denotes a very high descriptive level.

TABLE 1. Level of corporate reputation, knowledge sharing, and intellectual capital of commercial banks

\begin{tabular}{llll}
\hline \hline Variables & SD & Mean & Descriptive Level \\
\hline Corporate reputation & 0.29 & 4.67 & Very high \\
Knowledge sharing & 0.43 & 4.33 & Very high \\
Intellectual capital & 0.34 & 4.63 & Very high \\
\hline \hline
\end{tabular}

The very high level means that corporate reputation, knowledge sharing, and intellectual capital are always manifested as perceived by the respondents.

\section{Correlation between Corporate Reputation and Knowl-} edge Sharing as well as Intellectual Capital and Knowledge Sharing

Reflected in Table 2 are the correlations between corporate reputation and knowledge sharing as well as intellectual capital and knowledge sharing among commercial banks. This led to the rejection of the null hypothesis. Thus, corporate reputation and knowledge sharing do have significant relationships with each other. Moreover, the overall $r$-value of 0.648 indicates a significant relationship $(p<0.05)$ between intellectual capital and knowledge sharing. Thus, this result led to the rejection of the null hypothesis.

TABLE 2. Correlation between corporate reputation and knowledge sharing and intellectual capital and knowledge sharing

\begin{tabular}{ll}
\hline \hline Variables & Overall \\
\hline Corporate Reputation and Knowledge Sharing & $0.491^{*}$ \\
& 0.000 \\
Intellectual Capital and Knowledge Sharing & $0.648^{*}$ \\
& 0.000 \\
\hline \hline
\end{tabular}


Moderating Effect of Intellectual Capital on the Relationship between Corporate Reputation and Knowledge Sharing

To determine the significance of the moderating effect of intellectual capital on the relationship between corporate reputation and knowledge sharing, a hierarchical regression analysis was utilized to fit its purpose. This is reflected in Table 3 as the primary source of data for Tables 4 and Table 5 which are both essential in the formulation of modgraph as can be distinctively seen in Figure 2 .

The moderating effect was exhibited on the premise that the higher is the level of intellectual capital of commercial banks, the higher is the effect of corporate reputation towards their knowledge sharing when compared to those with lower intellectual capital. Intellectual capital served as the moderating variable, corporate reputation as the independent variable, and knowledge sharing as the dependent variable. The corporate reputation variable was multiplied with the intellectual variable to yield an interaction term. The two main effects and the interaction term (corporate reputation $\mathrm{x}$ intellectual capital) were utilized in a hierarchical regression to predict knowledge sharing.

TABLE 3. Hierarchical regression to assess the moderating effect of intellectual capital on corporate reputation to knowledge sharing relationship

\begin{tabular}{|c|c|c|c|c|c|c|}
\hline \multirow[t]{2}{*}{ Model } & \multicolumn{2}{|c|}{ Unstandardized Coefficients } & \multirow{2}{*}{$\begin{array}{l}\text { Standardized Coefficients } \\
\beta\end{array}$} & \multirow[t]{2}{*}{$t$} & \multirow[t]{2}{*}{ Sig. } & \multirow[t]{2}{*}{$R^{2}$ Change } \\
\hline & $\beta$ & $\begin{array}{l}\text { Std. Er- } \\
\text { ror }\end{array}$ & & & & \\
\hline Step 1 & & & & & & .241 \\
\hline (Constant) & .923 & .304 & & 3.038 & .003 & \\
\hline Corporate reputation & .731 & .065 & .491 & 11.246 & .000 & \\
\hline Step 2 & & & & & & .191 \\
\hline (Constant) & .060 & .274 & & .220 & .826 & \\
\hline Corporate reputation & .211 & .072 & .142 & 2.925 & .004 & \\
\hline Intellectual capital & .711 & .061 & .560 & 11.565 & .000 & \\
\hline Step 3 & & & & & & .011 \\
\hline (Constant) & 7.886 & 2.826 & & 2.791 & .006 & \\
\hline Corporate reputation & -1.498 & .618 & -1.006 & -2.423 & .016 & \\
\hline Intellectual capital & -1.047 & .634 & -.825 & -1.650 & .100 & \\
\hline $\begin{array}{l}\text { Corporate reputation } \\
\text { by intellectual capital }\end{array}$ & .382 & .137 & 2.287 & 2.783 & .006 & \\
\hline
\end{tabular}

When regressing corporate reputation and intellectual capital in the step 2 regression, the model manifested to be significant $(p<.05)$ and demonstrated a change in $R$-square of 0.191 . The $R$-square change described how much variance in the dependent variable (knowledge sharing) these predictors explained in each step. The $R$-square change of 0.191 signified an additional variance of $19 \%$ to the variance of $24 \%$ in the step 1 regression showing that $24 \%$ of the variance in knowledge sharing of commercial banks was due to corporate reputation itself. The interaction term explained about $1.1 \%$ new variance above and beyond the two main effects. This was marked less than the change in Rsquare in step 1 and step 2 . Interestingly, the ANOVA was significant $(p<.05)$ suggesting that the interaction effect was a contributor to the model variance.

The significant interaction effect manifested that those bank employees with higher intellectual capital have higher level of knowledge sharing. The main effect was qualified by the significant interaction $(\beta=2.287, p<0.05)$ which was graphed in Figure 2. To have the modgraph, the unstandardized coefficient of the interaction term in the step 3 regression in Table 3 was employed and presented in Table 5 , supported with the descriptive statistics of each variable and the computed values of the main effects of corporate reputation and intellectual capital on knowledge sharing in Table 4. The figure demonstrated that those with high intellectual capital signified a steeper slope between corporate reputation and knowledge sharing than those with low intellectual capital, rejecting the null hypothesis. Thus, it can be stipulated that intellectual capital significantly moderates the relationship between corporate reputation and knowledge sharing of commercial banks in the said region. 
TABLE 4. Summary of means on the main effects of corporate reputation and knowledge sharing on intellectual capital

\begin{tabular}{llll}
\hline \hline Corporate Reputation & \multicolumn{3}{l}{ Intellectual Capital } \\
& Low & Medium & High \\
\hline High & 4.4349 & 4.5495 & 4.6641 \\
Medium & 4.2243 & 4.3020 & 4.3797 \\
Low & 4.0137 & 4.0546 & 4.0954 \\
\hline \hline
\end{tabular}

TABLE 5. Statistical output necessary to graph the main effects of corporate reputation and intellectual capital and the interaction on knowledge sharing

\begin{tabular}{llll}
\hline \hline Variable & $\beta$ & Mean & SD \\
\hline Corporate reputation & -1.498 & 4.6668 & .28686 \\
Intellectual capital & -1.047 & 4.6307 & .33636 \\
Interaction term & .382 & & \\
Constant & 7.886 & & \\
\hline \hline
\end{tabular}

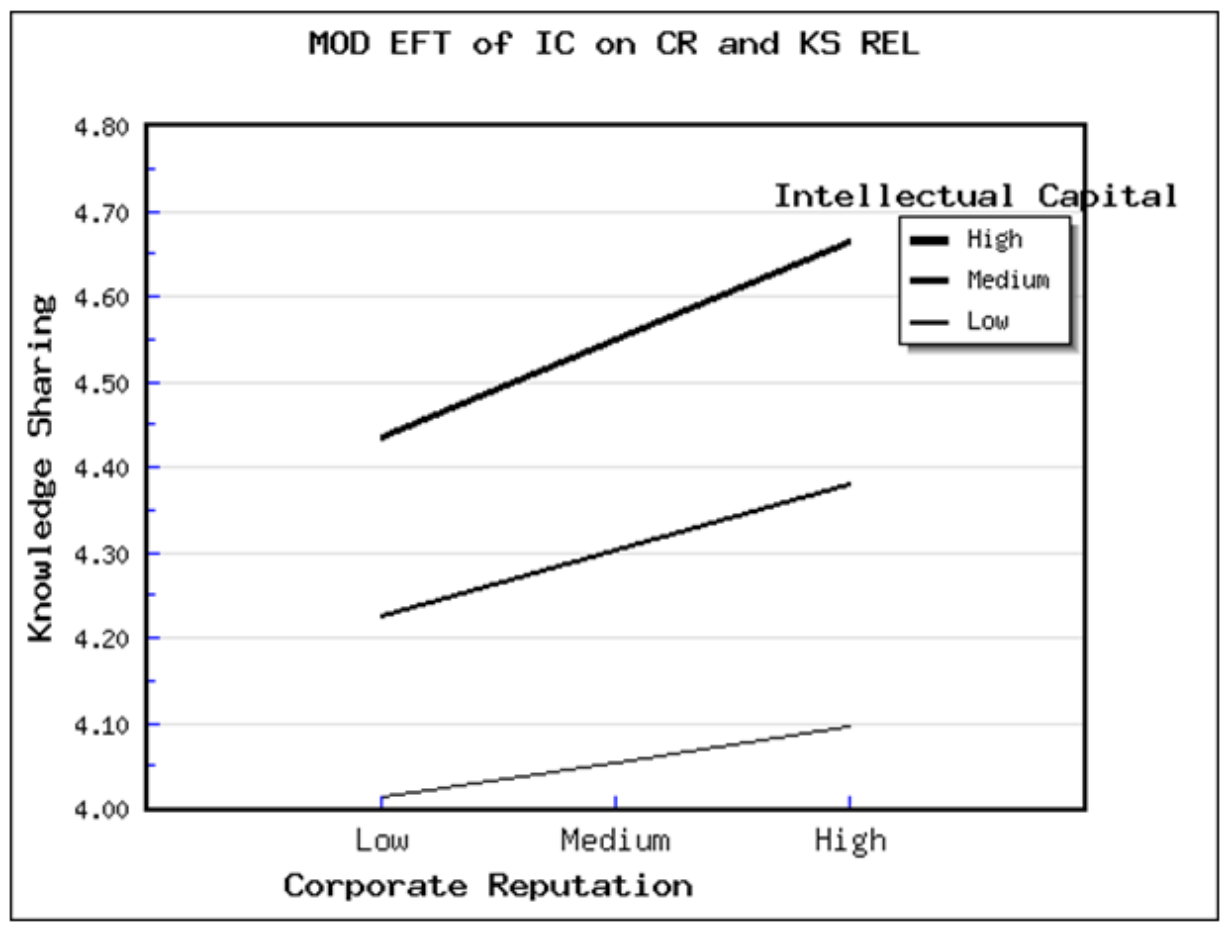

FIGURE 2. Graphical depiction of the moderating effect of intellectual capital on the corporate reputation-to-knowledge sharing relationshi

\section{DISCUSSION}

The Level of Corporate Reputation, Knowledge Sharing, and Intellectual Capital of Commercial Banks

The very high level of corporate reputation of commercial banks is attributed to the bank's promising of offering good quality products and services to its clients and good financial performance. Knowledge sharing indicated an overall result of remarkably very high level. This is evident for commercial bank employees who have established time and effort in the process of transferring organizational knowledge, most especially to those who are involved in making decisions. The very high level of knowledge sharing is confirmed by Hejase et al. (2014) purporting that employees who enjoyed the culture of sharing knowledge, trusting their peers to help them, and providing management support and encouragement, were more likely to share knowl- 
edge with others. Intellectual capital demonstrated an overall descriptive level of very high. The findings of the study revealed that human resources have accumulated their capabilities as responsible individuals in providing customer solutions by having highly competent management team. Kumari, Usmani, and Hussain (2014) contend that not only the effectiveness of teamwork is demonstrated by responsible leaders but also the intellectual capital that is nurtured in the organizations.

\section{Correlation between Corporate Reputation and Knowl- edge Sharing and Intellectual Capital and Knowledge Sharing}

The overall result on the correlation of the constructs reveals that corporate reputation is significantly related to knowledge sharing. In the holistic point of view, corporate reputation is always manifested and is positively associated with knowledge sharing and, therefore, rejects the null hypothesis of there is no significant relationship between corporate reputation and knowledge sharing. Similar findings of various studies have also been revealed by several authors (Wasko \& Faraj, 2005; Welschen, Todorova, \& Mills, 2012).

The study is contrary to the assertion of Mallasi and Ainin (2015) where their results revealed that reputation proved no significant evidence to support its relationship with knowledge sharing among postgraduate students. In the same vein, intellectual capital and knowledge sharing prove a positive correlation as demonstrated in the overall result. This portrays a significant relationship between these two constructs. Additionally, this reveals that the null hypothesis of there is no significant relationship between intellectual capital construct and knowledge sharing construct is rejected. The findings of this study are also corroborated by the following authors (Arabrahmatipour, Foroutan Rad, Beyramzadegan, \& Mohammadalipour, 2015; Mathuramaytha, 2014; Obeidat, Abdallah, Aqqad, Akhoershiedah, \& Maqableh, 2016).

\section{The Moderating Effect of Intellectual Capital on the Re- lationship between Corporate Reputation and Knowl- edge Sharing}

The results reveal that corporate reputation predicts knowledge sharing and intellectual capital also predicts knowledge sharing. To validate the existence of the moderation analysis, a ModGraph program (Jose, 2008) was utilized and facilitated to compute the cell means and generate its significant interaction for the graphical display. This allowed further information processing from the regression analysis to visually examine the statistical interactions. The graph (see Figure 2) proves that intellectual capital significantly moderates the relationship between corporate reputation and knowledge sharing. This means that commercial bank employees with higher intellectual capital do enforce higher level of corporate reputation towards knowledge sharing as compared to those with lower intellectual capital. Since the effect is higher at higher level, a significant moderating effect occurred as the rule implied that such interaction would exist when the graphs would have different gradients as well as the slope and the lines do not form in parallel according to Aiken, West, and Reno (1991) and Jose (2008). Stevens (2000) also emphasized that such significant interaction effect would result when lines do not cross and that the slope of lines should not be parallel in an ordinal interaction given enough statistical power. This moderating relationship may be considered as a new contribution to the body of knowledge, especially that combining these constructs in a single study is relatively sparse in the academic literature.

Individual intellectual capital resources (Marr, 2008) interrelate with other tangible and intangible resources, such as reputation and knowledge sharing to form core competencies. Similarly, the strategic role of corporate reputation (Martínez García de Leaniz \& Rodríguez del Bosque, 2013) in obtaining its competitive advantage and relational capital depicts a vital support and that (Ansari, Roodbari, Aboosaeidi, \& Nassaji, 2016) both knowledge assets and intellectual capital are getting into strategic leverage to properly handle the performance of the business and providing a constant innovation of organizations. With this essential contribution, reputation (A. D. Smith, Rupp, \& Motley, 2013; Sihite, Sule, Azis, \& Kaltum, 2016), intellectual capital (Chahal \& Bakshi, 2014; Martínez García de Leaniz \& Rodríguez del Bosque, 2013), and knowledge sharing (Abdul-Jalal, Toulson, \& Tweed, 2013) determine a strong and inimitable competitive advantage. The findings further support the study of Kariuki and Kiambati (2017) as the researchers also establish that those organizations with high intellectual capital outperform those with low profile of intellectual capital. Wei and Hooi (2009) also posited in their study that the empirical evidence of what intellectual capital can contribute to the organizations is an essential element as a gateway towards the organization's success, especially on its financial objectives. Moreover, business organizations with higher intellectual capital (Khan, Ali, et al., 2017) observe enterprise risk management practices to achieve superior market performance. Ozkan, Cakan, and Kayacan (2017) opined that intellectual capital made a sig- 
nificant contribution to value creation and raising the firm's performance. The study is also supported on the findings of Lipunga (2014) who opines that commercial banks have to put more effort to improve their intellectual capital efficiency. Moreover, as the study also discloses that a significant main effect of intellectual capital is also achieved, it also implies that employees in commercial banks having higher intellectual capital level have also higher level of knowledge sharing. This main effect was supported by the significant interaction between corporate reputation (IV) and intellectual capital (MV). Other research scholars also validated this study as a common ground of agreement that intellectual capital made significant effects on corporate reputation (Abeysekera, 2010; Hitt, Bierman, Shimizu, \& Kochhar, 2001; Kariuki, 2014). Managers are encouraged to provide (Ansari et al., 2016) an environment that is conducive for the minds of the individuals.

\section{CONCLUSION \& IMPLICATIONS}

The result of the study indicates that the levels of corporate reputation, knowledge sharing, and intellectual capital of commercial banks prove to be very high. On the other hand, the correlation between corporate reputation and knowledge sharing purports a significant relationship, thus rejecting the null hypothesis. Similarly, a significant relationship also exists when intellectual capital and knowledge sharing are correlated, pointing to the rejection of the null hypothesis. Likewise, intellectual capital significantly moderates the relationship between corporate reputation and knowledge sharing. Having said this, the proposed research model in this study may be utilized by the business enterprises, in general, by revisiting their current platforms and policy review on corporate governance on corporate reputation towards knowledge sharing with the complement of intellectual capital. This research may be translated into practical management guidelines in order for the banking and other sectors to appreciate the use of corporate reputation, intellectual capital, and knowledge sharing. The very need to enrich a more comprehensive understanding of the results and findings suggests for more longitudinal studies as avenues for future research since this proposed framework may be considered as a new contribution and the related literature combining these constructs in one single study is sparse. Statistical results and implications of this study may contribute to further development and expansion of research. Thus, this study is expected to generate more essential contribution to the scientific frontiers of knowledge, business practitioners, management side, and the corporate firms.

\section{REFERENCES}

Abdul-Jalal, H., Toulson, P., \& Tweed, D. (2013). Knowledge sharing success for sustaining organizational competitive advantage. Procedia Economics and Finance, 7, 150-157. doi:https://doi.org/10.1016/s2212-5671(13)00229-3

Abdullah, D. F., \& Sofian, S. (2012). The relationship between intellectual capital and corporate performance. Procedia-Social and Behavioral Sciences, 40, 537-541. doi:https://doi.org/10.1016/j.sbspro.2012.03.227

Abeysekera, I. (2010). The influence of board size on intellectual capital disclosure by kenyan listed firms. Journal of Intellectual Capital, 11(4), 504-518. doi:https://doi.org/10.1108/14691931011085650

Aiken, L. S., West, S. G., \& Reno, R. R. (1991). Multiple regression: Testing and interpreting interactions. New York, NY: Sage.

Alshehhi, A. S. (2016). Organizational knowledge systems. International Journal of Business and Administrative Studies, 2(6), 193-200. doi:https://doi.org/10.20469/ijbas.2.10004-6

Ansari, S., Roodbari, A., Aboosaeidi, L. R., \& Nassaji, H. (2016). Intellectual capital as the facilitating infrastructure of knowledge creating and sharing. International Journal of Economics, Commerce and Management, 4(6), 100-117.

Arabrahmatipour, M., Foroutan Rad, L., Beyramzadegan, S., \& Mohammadalipour, N. (2015). Evaluating the relationship between intellectual capital and knowledge sharing among librarians in tehran university of medical sciences. Journal of Humanities and Social Science, 20(10), 92-98.

Bo Shing, . X. P., L. A. (2017). Exploring the relationship between leadership, organizational culture, trust, and effectiveness of knowledge sharing by forced learning. Journal of Administrative and Business Studies, 3(2), 89-104. doi:https:// doi.org/10.20474/jabs-3.2.4

Bromley, D. B. (2001). Relationships between personal and corporate reputation. European Journal of Marketing, 35(3/4), 316-334. doi:https://doi.org/10.1108/03090560110382048

Chahal, H., \& Bakshi, P. (2014). Effect of intellectual capital on competitive advantage and business performance: Role of innovation and learning culture. International Journal of Learning and Intellectual Capital, 11(1), 52-70. doi:https:// doi.org/10.1504/ijlic.2014.059227 
Chang, W. S., \& Hsieh, J. J. (2011). Intellectual capital and value creation-is innovation capital a missing link? International Journal of Business and Management, 6(2), 3-10. doi:https://doi.org/10.5539/ijbm.v6n2p3

Chen, C. C. (2017). The use of corporate reputation in the development of brand image strategy in the Taiwanese pharmaceutical industry. International Studies of Management \& Organization, 47(3), 240-257. doi:https://doi.org/10.1080/ 00208825.2017.1318019

Chennamaneni, A. (2007). Determinants of knowledge sharing behaviors: Developing and testing an integrated theoretical model. Behaviour \& Information Technology, 31(11), 1097-1115. doi:https://doi.org/10.1080/0144929x.2011 .624637

Due Au, T. (2016). Using open innovation model to enhance knowledge sharing in Vietnam university. Journal of Administrative and Business Studies., 2(5), 241-247. doi:https://doi.org/10.20474/jabs-2.5.4

Emelo, R. (2012). Why personal reputation matters in virtual knowledge sharing. Industrial and Commercial Training, 44(1), 35-40. doi:https://doi.org/10.1108/00197851211193408

Ensign, P. , \& Hébert, L. (2010). How reputation affects knowledge sharing among colleagues. MIT Sloan Management Review, 51(2), 79-102. doi:https://doi.org/10.1057/9780230617131_5

Fernie, S., Green, S. D., Weller, S. J., \& Newcombe, R. (2003). Knowledge sharing: Context, confusion and controversy. International Journal of Project Management, 21(3), 177-187. doi:https://doi.org/10.1016/s0263-7863(02)00092-3

Fombrun, C. J. (1995). Reputation: Realizing value from the corporate image. Boston, MA: \{Harvard Business School Press\}.

Gardberg, N. A., \& Fombrun, C. J. (2002). The global reputation quotient project: First steps towards a cross nationally valid measure of corporate reputation. Corporate Reputation Review, 4(4), 303-307. doi:https://doi.org/10.1057/ palgrave.crr.1540151

Grupp, R. W., \& Gaines Ross, L. (2002). Reputation management in the biotechnology industry. Journal of Commercial Biotechnology, 9(1), 17-26. doi:https://doi.org/10.1057/palgrave.jcb.3040003

Hejase, H. J., Haddad, Z., Hamdar, B., Al, A., Rola, H., Ale, J., \& Beyrouti, N. (2014). Knowledge sharing: Assessment of factors affecting employee'motivation and behavior in the Lebanese organizations. Journal of Scientific Research \& Reports, 3(12), 1549-1593. doi:https://doi.org/10.9734/jsrr/2014/8107

Herbig, P., \& Milewicz, J. (1995). The relationship of reputation and credibility to brand success. Journal of consumer marketing, 12(4), 5-11. doi:https://doi.org/10.1108/eum0000000002601

Hinds, P. J., Patterson, M., \& Pfeffer, J. (2001). Bothered by abstraction: The effect of expertise on knowledge transfer and subsequent novice performance. Journal of Applied Psychology, 86(6), 1232. doi:https://doi.org/10.1037//0021 $-9010.86 .6 .1232$

Hitt, M. A., Bierman, L., Shimizu, K., \& Kochhar, R. (2001). Direct and moderating effects of human capital on strategy and performance in professional service firms: A resource-based perspective. Academy of Management journal, 44(1), 13-28. doi:https://doi.org/10.5465/3069334

Ismail, M. (2005). The influence of intellectual capital on the performance of Telekom Malaysia (Doctoral dissertation). Universiti Teknologi Malaysia, Johor Bahru, Malaysia.

Jose, P. E. (2008). Modgraph-i: A programme to compute cell means for the graphical display of moderational analyses: The internet version. Retrieved from https://goo.gl/qfpZ9h (accessed on 3 April 2010)

Kariuki, A. (2014). Intellectual capital, corporate reputation, corporate culture and performance of firms listed at the Nairobi securities exchange (Unpublished Ph. D thesis). School of Business, University of Nairobi, Nairobi, Kenya.

Kariuki, A., \& Kiambati, K. (2017). Intellectual capital, corporate culture and performance of firms listed on nairobi securities exchange. Management, 5(6), 508-524. doi:https://doi.org/10.17265/2328-2185/2017.06.004

Ketsiri, . P. P., K. (2016). Knowledge and understanding of accountants toward rules for calculating net income for corporate income tax by section 65 ter in Thailand. International Journal of Business and Economic Affairs, 1(1), 67-73. doi: https://doi.org/10.24088/ijbea-2016-11009

Khan, S. N., Ali, E. I. E., et al. (2017). The moderating role of intellectual capital between enterprise risk management and firm performance: A conceptual review. American Journal of Social Sciences and Humanities, 2(1), 9-15. doi:https:// doi.org/10.20448/801.21.9.15

Kinata, E. J. (2016). The effect of market volatility and firm size towards the difference of market reaction around stock-split announcement in Indonesia stock exchange. Journal of Administrative and Business Studies, 2(6), 304-313. doi:https:// 
doi.org/10.20474/jabs-2.6.5

King, W. R. (2009). Knowledge management and organizational learning. Boston, MA: Springer.

Klein, P. (1999). Measure what matters: You can measure your organization's reputation-without breaking the bank-with some of today's new tools. Communication World, 16, 32-36.

Kumari, K., Usmani, S., \& Hussain, J. (2014). Responsible leadership and intellectual capital: The mediating effects of effective team work. Journal of Economics, Business and Management, 3(2), 176-182. doi:https://doi.org/10.7763/joebm.2015 .v3.176

Lannu, . N. M. F. L., J. E. (2017). The impact of competitiveness on the employability of Philippines industrial designers: Streamlining the program with the international market. International Journal of Business and Administrative Studies, 3(1), 30-36. doi:https://doi.org/10.20469/ijbas.3.10005-1

Lin, R.-J., Che, R.-H., \& Ting, C.-Y. (2012). Turning knowledge management into innovation in the high-tech industry. Industrial Management \& Data Systems, 112(1), 42-63. doi:https://doi.org/10.1108/02635571211193635

Lipunga, A. M. (2014). Intellectual capital performance of the commercial banking sector of malawi. International Journal of Business and Management, 10(1), 210-216. doi:https://doi.org/10.5539/ijbm.v10n1p210

Mallasi, H., \& Ainin, S. (2015). Investigating knowledge sharing behaviour in academic environment. Journal of Organizational Knowledge Management, 2015, 1-19.

Marr, B. (2008). Impacting future value: How to manage your intellectual capital. Retrieved from https://goo.gl/3sEgD2

Martínez García de Leaniz, P., \& Rodríguez del Bosque, I. (2013). Intellectual capital and relational capital: The role of sustainability in developing corporate reputation. Intangible Capital, 9(1), 262-280. doi:https://doi.org/10.3926/ ic.378

Mathuramaytha, C. (2014). An empirical study of the influence of intellectual capital on knowledge-sharing capability and export performance in thailand industries. International Journal of Applied Business and Economic Research, 12(3), 465-478.

McGrane, S. J. (2016). Knowledge sharing in multicultural organizations. Retrieved from https://goo.gl/NSd3rR (accessd on 26 April 2017)

Michailova, S., \& Husted, K. (2003). Knowledge-sharing hostility in Russian firms. California Management Review, 45(3), 59-77. doi:https://doi.org/10.2307/41166176

Musteen, M., Datta, D. K., \& Kemmerer, B. (2010). Corporate reputation: Do board characteristics matter? British Journal of Management, 21(2), 498-510. doi:https://doi.org/10.1111/j.1467-8551.2009.00676.x

Ngah, R., \& Ibrahim, A. R. (2011). The influence of intellectual capital on knowledge sharing: small and medium enterprises' perspective. Communications of the IBIMA, 4(6), 1-13. doi:https://doi.org/10.5171/2011.444770

Nguyen, N., \& Leblanc, G. (2001). Corporate image and corporate reputation in customers' retention decisions in services. Journal of retailing and Consumer Services, 8(4), 227-236. doi:https://doi.org/10.1016/s0969-6989(00)00029-1

Noe, R. A. (2008). Employee training and development. New York, NY: McGraw-Hill/Irwin.

Obeidat, B. Y., Abdallah, A. B., Aqqad, N. O., Akhoershiedah, A. H. O. M., \& Maqableh, M. (2016). The effect of intellectual capital on organizational performance: The mediating role of knowledge sharing. Communications and Network, 9(01), 1-27. doi:https://doi.org/10.4236/cn.2017.91001

Oye, N., Salleh, M., \& Noorminshah, A. (2011). Knowledge sharing in workplace: Motivators and demotivators. International Journal of Managing Information Technology, 3(4), 71-84. doi:https://doi.org/10.5121/ijmit.2011.3406

Ozkan, N., Cakan, S., \& Kayacan, M. (2017). Intellectual capital and financial performance: A study of the turkish banking sector. Borsa Istanbul Review, 17(3), 190-198. doi:https://doi.org/10.1016/j.bir.2016.03.001

Renzl, B. (2008). Trust in management and knowledge sharing: The mediating effects of fear and knowledge documentation. Omega, 36(2), 206-220. doi:https://doi.org/10.1016/j.omega.2006.06.005

Rindova, V. P., Williamson, I. O., Petkova, A. P., \& Sever, J. M. (2005). Being good or being known: An empirical examination of the dimensions, antecedents, and consequences of organizational reputation. Academy of Management Journal, 48(6), 1033-1049. doi:https://doi.org/10.5465/amj.2005.19573108

Sihite, M., Sule, E. T., Azis, Y., \& Kaltum, U. (2016). Gain competitive advantage through reputation. South East Asia Journal of Contemporary Business, Economics and Law, 10(3), 22-31. 
Smith, A. D., Rupp, W. T., \& Motley, D. (2013). Corporate reputation as strategic competitive advantage of manufacturing and service-based firms: multi-industry case study. International Journal of Services and Operations Management, 14(2), 131-156. doi:https://doi.org/10.1504/ijsom.2013.051826

Smith, K. T., Smith, M., \& Wang, K. (2010). Does brand management of corporate reputation translate into higher market value? Journal of Strategic Marketing, 18(3), 201-221. doi:https://doi.org/10.1080/09652540903537030

Stevens, J. J. (2000). Interaction effects in regression. Retrieved from https://goo.gl/jR3iKT (accessed on 14 July 2017)

Stewart, T. A. (1997). Intellectual cpital: The wealth of new organizations, currency. New York, NY: Doubleday.

Stewart, T. A. (2007). The wealth of knowledge: Intellectual capital and the twenty-first century organization. Danvers, MA: Crown Business.

Tsang, T. (2015). Mediating and moderating variables explained. Retrieved from https://goo.gl/CzuYbx (accessed on 21 June 2018)

Walsh, G., Mitchell, V. W., Jackson, P. R., \& Beatty, S. E. (2009). Examining the antecedents and consequences of corporate reputation: A customer perspective. British Journal of Management, 20(2), 187-203. doi:https://doi.org/10.1111/ j.1467-8551.2007.00557.x

Wasike, C. N. (2017). Financial regulation as moderating, influence of corporate governance, institutional quality, human capital and firm size on financial institutions performance in Kenya. Journal of Administrative and Business Studies, 3(6), 292-304. doi:https://doi.org/10.20474/jabs-3.6.4

Wasko, M. M., \& Faraj, S. (2005). Why should i share? Examining social capital and knowledge contribution in electronic networks of practice. MIS quarterly, 29(1), 35-57. doi:https://doi.org/10.2307/25148667

Wei, I., Kiong. Ting., \& Hooi, L. H. (2009). Intellectual capital performance of financial institutions in malaysia. Journal of Intellectual capital, 10(4), 588-599. doi:https://doi.org/10.1108/14691930910996661

Welschen, J., Todorova, N., \& Mills, A. M. (2012). An investigation of the impact of intrinsic motivation on organizational knowledge sharing. International Journal of Knowledge Management, 8(2), 23-42. doi:https://doi.org/10.4018/jkm .2012040102

Wenger, E., McDermott, R. A., \& Snyder, W. (2002). Cultivating communities of practice: A guide to managing knowledge. Boston, MA: Harvard Business Press. 